\title{
Local preferences for three indigenous oil- seed plants and attitudes towards their conservation in the Kénédougou province of Burkina Faso, West-Africa
}

Fanta Reine Sheirita Tiétiambou ${ }^{1,2^{*}}$, Kolawolé Valère Salako ${ }^{3,4} \mathbb{B}$, Jésukpégo Roméo Tohoun ${ }^{3}$ and Amadé Ouédraogo ${ }^{2}$

\begin{abstract}
Background: Carapa procera, Lophira lanceolata, and Pentadesma butyracea are three underutilized but increasingly threatened indigenous oil-seed tree species (IOS) in tropical Africa. Because local knowledge is vital for sustainable management, this study investigated the socio-economic factors that explain local people's (i) preferences for these IOS, (ii) attitudes toward their conservation, and (iii) ability to identify "plus trees" based on seed traits. We predicted a positive relationship between response variables and informants' age, residence status, gender (femaleness), and existence of market opportunities for each IOS. We also predicted that a higher preference for a given IOS has a positive effect on people's attitudes for its conservation and the aptitude to identify its "plus trees." We additionally expected significant differences among ethnic groups for each response variable.

Methods: Data were collected through individual semi-structured interviews with 336 informants from 14 randomly selected villages in the species distribution area of Kénédougou province. For each species, the collected data were the number of actual uses reported (converted to use value-UV, as a measure of the species preference), practiced conservation actions (converted to conservation attitude using a four-scale scoring method), and possible criteria for selecting preferred trees for seed oil extraction. Generalized linear mixed models were used to test for the fixed effects of socio-economic factors, and account for the random variation across villages.

(Continued on next page)
\end{abstract}

\footnotetext{
* Correspondence: tietiambou.fanta@gmail.com

'Centre Universitaire de Gaoua, Université Nazi BONI, 01 BP 1091,

Bobo-Dioulasso 01, Burkina Faso

Laboratoire de Biologie et Ecologie Végétales, Université Joseph KI-ZERBO,

03 BP 7021, Ouagadougou 03, Burkina Faso

Full list of author information is available at the end of the article
}

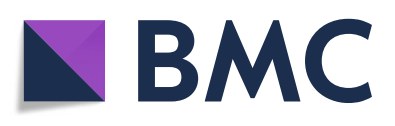

(- The Author(s). 2020 Open Access This article is licensed under a Creative Commons Attribution 4.0 International License, which permits use, sharing, adaptation, distribution and reproduction in any medium or format, as long as you give appropriate credit to the original author(s) and the source, provide a link to the Creative Commons licence, and indicate if changes were made. The images or other third party material in this article are included in the article's Creative Commons licence, unless indicated otherwise in a credit line to the material. If material is not included in the article's Creative Commons licence and your intended use is not permitted by statutory regulation or exceeds the permitted use, you will need to obtain permission directly from the copyright holder. To view a copy of this licence, visit http://creativecommons.org/licenses/by/4.0/ The Creative Commons Public Domain Dedication waiver (http://creativecommons.org/publicdomain/zero/1.0/) applies to the data made available in this article, unless otherwise stated in a credit line to the data. 
(Continued from previous page)

Results: The results showed species-specific patterns. Carapa procera had the highest UV and hence was the most preferred IOS, particularly by women. Informants from the Siamou ethnic group had the highest UV irrespective of IOS. The most cited conservation actions were assisted natural regeneration and banning of tree cutting, which were practiced for C. procera and L. lanceolata. No conservation measure was cited for P. butyracea. The practice of tree planting was not recorded for any of the IOS. Young and male informants participated less in conservation actions. Tree selection for oil-seed collection was mainly guided not by "oil extraction yield" but rather by the "quality of extracted oil" (namely oil color and taste for food uses, and oil bitterness for medicinal efficacy). The selection mainly concerned L. lanceolata and was mostly practiced by elderly people.

Conclusion: This study provided useful local knowledge-based information to guide conservation actions and valorization strategies of three IOS. The study sheds further light on the socio-economic factors that are associated to local people's preferences, conservation attitudes, and individual tree selection.

Keywords: Conservation actions, Local knowledge, Kénédougou, Plus-tree, Underutilized-plants, Use value

\section{Background}

Rural communities substantially rely on natural lands and resources for their livelihoods. They subsequently have good knowledge of their environmental resources $[1,2]$. This knowledge evolves through a dynamic process of knowledge acquisition and loss to adapt to changing living conditions and needs [3]. Increasingly, such knowledge has proven vital for conservation but also for the domestication of wild tree species with a high potential for being promoted. Some of these species are still underutilized and are threatened by several factors (e.g., overexploitation, habitat fragmentation, climate change, and invasive species). This is particularly the case for Carapa procera DC., Lophira lanceolata, Tiegh. ex Keay, and Pentadesma butyracea Sabine, three multipurpose indigenous oil-seed tree species in Western Burkina Faso [4, 5].

Carapa procera, locally called "Kobiyiri" in Djula (a common local language in the Western provinces of Burkina Faso), is a tree of $8-20 \mathrm{~m}$ height that naturally occurs in gallery forests of semi-arid regions [6]. The annual seed production per tree varies between $0.7 \mathrm{~kg}$ and $30.1 \mathrm{~kg}$ of dry material with an annual potential productivity of $1.02 \mathrm{t}^{\mathrm{h} \mathrm{h}^{-1}}$ [4]. Seed oil of this species is used as a component for human medicine, cosmetics, and biopesticides [5, 7]. The seed oil is sold on local markets in West Africa and the price varies between $€ 1.5$ and $€ 7.7$ per liter [4]. Lophira lanceolata, called "Mananyiri" in Djula, is a rather small tree of $8-10 \mathrm{~m}$ height occurring in the Sudano-Guinean and Guinean savannahs of Africa $[6,8]$. In Cameroon, a liter of seed oil from this species fluctuates between $€ 1.8$ and $€ 2.8$ on the local market [9]. Pentadesma butyracea, called "N'taman" in Djula, is a tree species of up to $10 \mathrm{~m}$ height and, like C. procera, it naturally occurs in gallery forests of semi-arid regions [6]. Its annual seed production varies between $0.7 \mathrm{~kg}$ and $20 \mathrm{~kg}$ of dry material per tree with an annual potential productivity of $0.36 \mathrm{t}^{-\mathrm{ha}^{-1}}$ [4]. Its seed oil is similar to that of shea butter and commonly used for human food and in cosmetics. In some West-African markets, $1 \mathrm{~L}$ of its oil is sold at $€ 2-8$ [10]. All three species are multipurpose trees with a high potential for seed oil extraction. Seeds of these species have a high content of oil, the therapeutic and cosmetic virtues of which are well documented in many African countries [5, 7, 10-12]. In Kénédougou, different parts of these plants are used by rural communities in cosmetics for body and hair care, pharmacopeia for health care, handcrafts for construction, and biopesticides for phytosanitary treatments [7, $13,14]$.

During recent decades, repeated and longer droughts in addition to habitats fragmentation due to extensive agriculture have put high pressures on tree species across the Sahel $[15,16]$. Overharvesting of fruits and seeds makes their natural stands vulnerable to aging because of the threat on natural regeneration $[2,14,17$, 18]. This is particularly true for C. procera, L. lanceolata, and $P$. butyracea the seeds of which provide high use value oils. Therefore, actions for conservation and cultivation of these species have become urgent to guarantee the current and future optional sustainable uses of their products.

In most developing countries, there is a global deficiency of government-driven policies to support the valorization, conservation, and cultivation of wild species. In Burkina Faso, most of the efforts were on exotic species (e.g., Anacardium occidentale L., Azadirachta indica A. Juss., Eucalyptus camaldulensis Dehn., and Mangifera indica L.) which were used in several tree planting programs as a strategy to mitigate the impacts of climate variability and change on farmers' food security and livelihoods [19]. Nonetheless, farmers themselves have developed some traditional conservation practices such as farmers' management of natural regeneration. They have even initiated cultivation (i.e., tree planting) of some indigenous species (e.g., Adansonia digitata, 
Vitellaria paradoxa, Ziziphus mauritiana) [19-22], the understanding of which provides important baseline information for further actions [23-25]. For example, in the Siamou ethnic group of Burkina-Faso in Kénédougou province, women raise seedlings of $C$. procera in nurseries and sell them to local people for plantation. Attitudes toward the conservation of species are, however, species-specific [26] and depend on several factors including the socio-demographic profiles (gender, age, education, ethnicity, etc.) of local people [19, 27], their geographical location and preferences (local importance of species: UV, market value) [28], and their knowledge on the species biology $[29,30]$. Traditional conservation and management actions are diverse and may range from plantations where a species is deliberately planted, to assisted natural regeneration (ANR). In ANR, seedlings and saplings of targeted species are protected and maintained for their survival and development; individuals of the species are not subject to logging [31]. Other species may not be the subject of any specific conservation and cultivation practices even though their local importance is recognized [31].

Indigenous oil-seed species (IOS) can display large morphological variations in their fruits, seeds, kernels, oil, etc. $[8,32,33]$, which results in interesting material variants (i.e., morphotypes or so-called plus trees) that are perceived and valued by local people. Therefore, individual trees presenting interesting characteristics might be particularly targeted for seed collection not only for consumption and other uses but also for conservation and possibly cultivation. It is subsequently expected that local people would have some local selection criteria of those materials [34]. However, there is a risk of genetic erosion due to underutilization or unsuitable management of the material perceived as "non-interesting" [34]. Species subject to such selections deserve particular conservation actions to guarantee the conservation of genetic resources. Understanding local people's ability to select plant materials, concerning their uses and conservation, therefore, has evident implications for the management of the genetic resources of the concerned species. It is expected that species with high use and market values will likely be subject to such selection as long as a morphological diversity is perceived and has implications for the quality of derived products.

In this study, we aimed to contribute to a better management of the three IOS by understanding local people's (i) preferences, (ii) attitudes toward conservation, and (iii) ability to identify the plus trees of C. procera, L. lanceolata, and P. butyracea in the Kénédougou province, Burkina Faso. The study was driven by a model of multiple hypotheses inspired by Whitney et al. [35] in regards to preferences for species, conservation of species, and selection of plus trees, and which are summarized in Fig. 1.
Theories suggest that an individual's socio-cultural and demographic characteristics such as gender, age, and ethnicity influence their preference or UV of a given species [27]. In particular, because women are specialized in the collection of non-timber forest products [36, 37] such as IOS (e.g., the shea butter tree Vitellaria paradoxa [38]), they are likely to have greater knowledge and UV of IOS. Similarly, knowledge accumulation is a time-dependent process, and older people are expected to have greater knowledge and hence utilize a species more than younger people [39]. Furthermore, due to historical differences in habits and customs, individuals belonging to different ethnic groups are likely to have different knowledge about the uses of a given species, even in the same geographical area $[40,41]$. Also, individuals belonging to the same ethnic group but living in a different geographical area can have different knowledge and values about a given species because other species better fulfill the role of that plant in different geographical locations [42]. Compared to non-residents, resident individuals might have more knowledge and value for a given species [5, 43]. For example, CuniSanchez et al. [44] reported that pastoralists identified fewer ecosystem services than resident farmers, used some ecosystem services differently, and had limited interest in forest conservation. Proximity to market opportunities for local resources has a positive impact on how local people value and use a given species [45]. In particular, species with market opportunities either local or regional are more inclined to be collected, used, and maintained than species with no market opportunities [46]. Moreover, people's preferences for a given species determine their conservation attitudes toward that species [26], such that species with a higher preference are expected to benefit from better conservation attitudes. Finally, people having higher preferences for a given species are likely to have a better knowledge of interesting material within that species and possibly select individuals with the most interesting traits for use, cultivation, and markets. Based on the above, and as illustrated in Fig. 1, we predicted a positive relationship between informants' age, residence status, gender, and existence of market opportunities, and each of our variables of interest namely preferences, conservation attitude, and ability to select plus trees of each IOS. We also predicted that a higher preference for a given IOS induces better conservation attitudes and a higher aptitude to identify plus trees of the IOS. We finally expected significant differences among ethnic groups regarding preferences, conservation attitude, and ability to select plus trees of each IOS; mainly because differences in habits, customs, and lifestyles which are inherent to ethnic groups, are likely to affect their perception, uses, valuation, and management of resources in their environment [44]. 


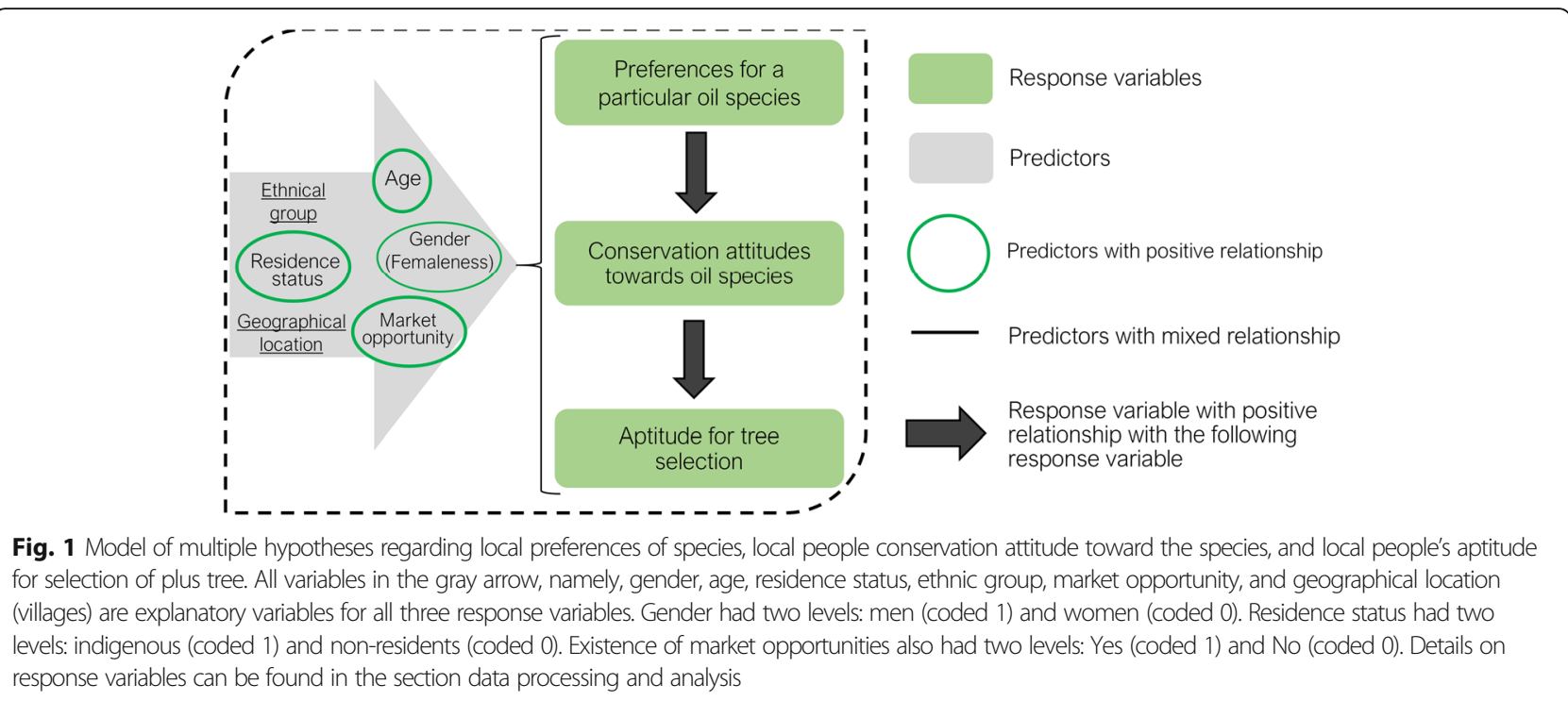

\section{Methods}

\section{Study area}

The study was carried out in Kénédougou province, located in the West of Burkina Faso in the south-Sudanian phytogeographic zone with a Sudanian climate (Fig. 2) [47]. This province covers $8403 \mathrm{~km}^{2}$, with 13 administrative communes including an urban one, Orodara, and 176 villages [43]. Kénédougou province is located in the rainiest part of the country and is an area of several humid savannahs and gallery forests, which are the habitats of the three species. From 1983 to 2014, the mean annual rainfall was $1008 \pm 164.7 \mathrm{~mm}$, and the annual temperature ranged from $25^{\circ} \mathrm{C}$ to $31{ }^{\circ} \mathrm{C}$. Inhabitants were estimated to be 334,751 people in 2011, shared among the Toussian, Bolon, Siamou, Fulani, and Sénoufo ethnic groups. The socio-economic activities are mainly agriculture, livestock breeding, and nontimber forest product collection.

\section{Sampling design and data collection}

Fourteen villages were selected from the distribution range of the three species using a random sampling scheme. For the selected villages, selection of informants was stratified, based on the four major ethnic groups in the province (i.e., Bolon, Siamou, Toussian, and Fulani). Sénoufou ethnic group was not considered because they were already part of a previous study [5]. Among these communities, Fulani are nomadic (non-residents) and the other three groups are indigenous. Eighty-four informants equally distributed between men and women and grouped into three age categories (young: $<20$ years old, adults: $20-50$ years old, and old persons: $>50$ years) [43] were randomly selected from each ethnic group, making a total sample size of $n=336$ interviewees. Individual semi-structured interviews were conducted using a questionnaire to collect data from informants about which of the IOS, they knew about, the different uses they knew and practiced for each species, and the used plant parts. Questions were also related to the informant's actions toward the conservation of each species. The responses could be "no action of conservation," "banning tree cutting," "assisted natural regeneration," or "tree planting" following Balima et al. [31]. Finally, informants were asked about their ability to recognize particular tree morphotypes (i.e., plus trees) with regards to their interesting traits for seed oil production, and if so, the criteria they used for such selection. Informants were also asked whether market opportunities exist for each of the three IOS products in their village.

\section{Data processing and analysis}

First, a preference for IOS by rural communities was captured through the calculation of the actual UV index (mean of the number of distinct actual uses reported per informant). It was assumed that a group with high UV for a species prefers that species more than a group with low UV; similarly, a species with high UV is more preferred than a species with low UV [48]. UV is a measure of species relative importance that combines species versatility (the number of distinct uses of a species) and popularity (the number of people who recognize a species as being useful) $[49,50]$. Thus, the preferences of informants for each species were measured based on their actual UV. We distinguished between theoretical (practiced and not practiced uses) and actual (practiced) uses, hence, theoretical and actual UV. We further examined for each species the correlation between theoretical UV and actual UV. Next, a four-scale scoring system was used for the attitudes toward IOS conservation as follow: "no action of conservation" (score $=0$ ); "banning tree 


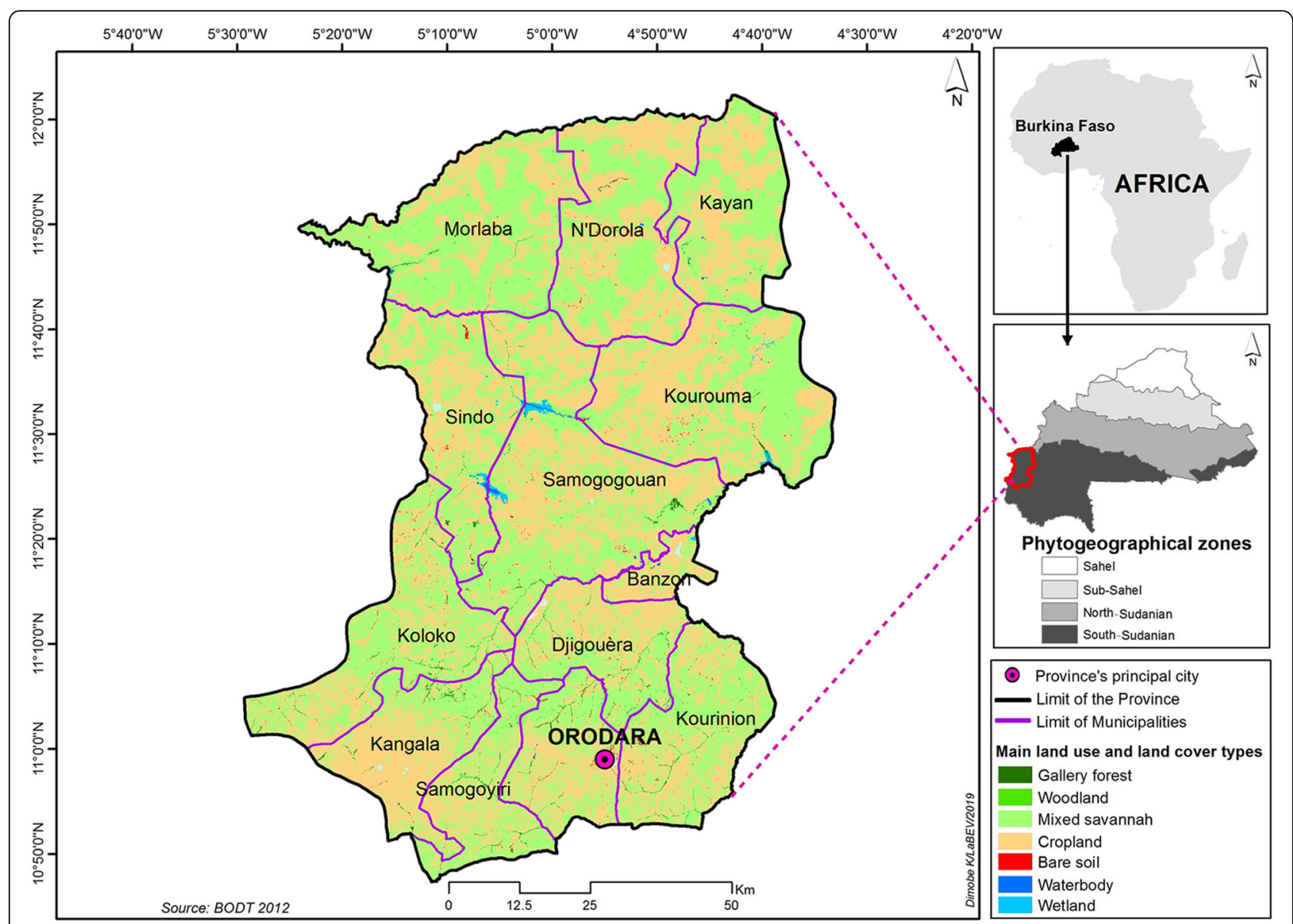

Fig. 2 Geographical location of the study area

cutting" (score = 1), "assisted natural regeneration" (score $=2$ ), and "planting trees" (score = 3) (hence, ordinal data). Finally, the aptitude for tree selection was considered as a binary response variable (Yes $=1$, No $=$ $0)$. A Poisson generalized linear mixed model [51], an ordinal logistic mixed model [52], and binomial logistic mixed model [51] were used to examine the effect of explanatory factors on the preference, attitudes toward conservation, and ability to identify plus trees, respectively, based on the multiple hypotheses diagram in Fig. 1. All factors in Fig. 1 were considered fixed, and the village was included as a random factor because the studied villages were selected randomly. This random effect was used as a measure of variation across geographical locations, after controlling for all other sources of variation. The model containing all explanatory variables and the random factor was first established. Then, the parsimonious model was selected using backward elimination based on likelihood ratio tests. By including the village as a random factor in the model, it was assumed that the fluctuation around the intercept, for each village, was normally distributed with a certain variance.
Thus, the higher the variance, the greater the differences among villages. The marginal and the conditional $R^{2}$ were extracted to compare the effect of the random factor to the fixed ones. Comparable values of marginal and conditional $R^{2}$ indicated that most of the variation explained in the models was due to fixed factors, rather than by village random effects. All statistical analyses were carried out with the $\mathrm{R}$ statistical software 3.3.0 [53]. The ordered logistic regression models were performed using the "ordinal" package [54]. The mixed Poisson and binomial logistic GLMM were performed using the "lme4" package [55].

\section{Results}

\section{Factors explaining the actual UV of IOS}

Carapa procera was the most known species (79\% of informants, Fig. 3a) whereas $P$. butyracea was the least known (3\%). However, theoretical knowledge on the uses of L. lanceolata was higher than that of C. procera and $P$. butyracea (Fig. 3b). The actual UV was significantly ( $p=$ 0.002, Poisson GLM) higher for C. procera $(0.61 \pm 0.06)$ and L. lanceolata $(0.44 \pm 0.03)$, the UV of which were > 


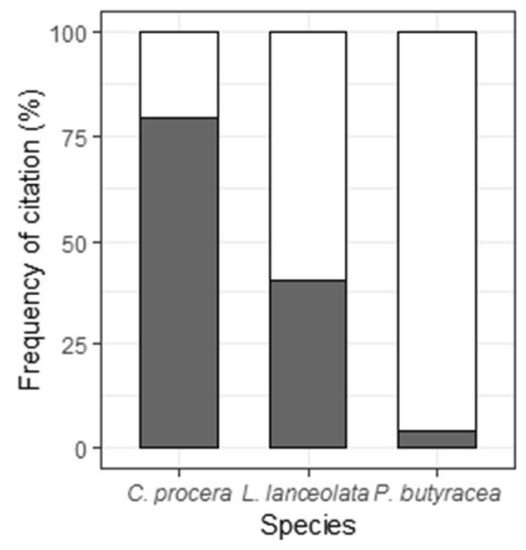

Fig. 3 Proportion of informants who knew the three IOS (a), and traditional theoretical knowledge of their uses (b) (a)
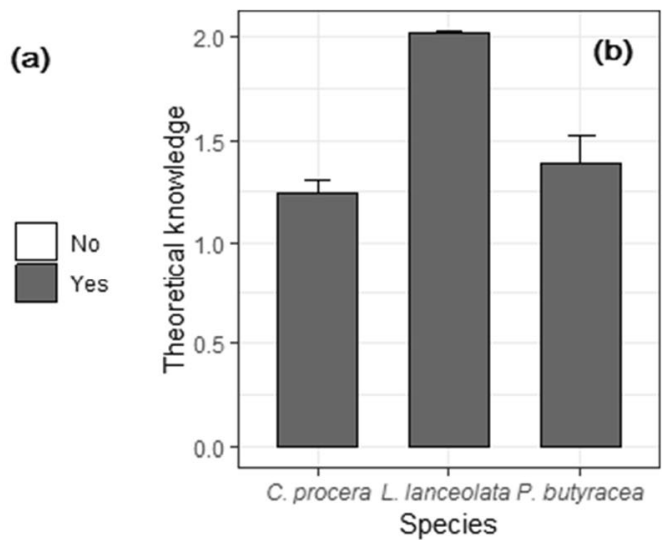

(b)
15 and 11 times higher, respectively, than that of $P$. butyracea $(0.04 \pm 0.01)$. There were also positive and significant $(p=0.001)$ correlations between theoretical and actual UV for each IOS: 0.43, 0.85 and 1.00 for C. procera, L. lanceolata, and $P$. butyracea, respectively.

Univariate models indicated significant effects of gender and ethnic group on UV of C. procera; gender, age, residence status, and ethnic group on UV of L. lanceolate; and residence status on UV of $P$. butyracea (Fig. 4). The parsimonious model from the model selection procedure indicated that socio-demographic factors associated with the actual UV were species-specific (Table 1). Only gender was significantly associated with the actual UV of C. procera, whereas informant age and ethnic group in addition to gender were significantly associated with the actual UV of $L$. lanceolata (Table 1). Only residence status was associated with the actual UV of P. butyracea (Table 1). Where a gender effect was significant, men had lower actual UV (Table 1 and Fig. 4a, b, c). Where age exhibited a significant effect, younger informants had lower actual UV compared to adult and old informants, who had similar actual UV (Table 1 and Fig. 4d, e, f). Where residence status had a significant effect, indigenous informants had higher actual UV (Table 1 and Fig. 4g, h, i). Concerning ethnic groups, informants from the Siamou ethnic group had the highest UV whereas Bolon had the lowest UV (Table 1 and Fig. 4j, k, l). Values of conditional and marginal $R^{2}$ showed that contrary to L. lanceolata (comparable values) for which the random effect of the village was negligible, for the other two species, there was greater variation among villages (large differences between both $R^{2}$ ) with respect to the actual UV (Table 1), reflecting the effect of geographical location.

\section{Factors affecting local people's attitudes towards IOS conservation \\ Overall pattern of conservation practices}

No conservation measure was recorded for P. butyracea in Kénédougou province. Tree planting was not recorded for any species (Fig. 5). Only ANR and banning of tree cutting were practiced for C. procera and L. lanceolata. People were relatively similarly engaged in ANR for L. lanceolata (15\%) and C. procera (13\%). However, they were more inclined to ban tree cutting for L. lanceolata (18\%) than for C. procera (only $3 \%$ ). Overall, whereas no conservation practice was recorded for $P$. butyracea, $L$. lanceolata received relatively better conservation attitudes than C. procera (Fig. 5).

\section{Factors affecting conservation attitudes towards IOS}

This analysis was done only for C. procera and L. lanceolata because no conservation measure was recorded for $P$. butyracea. Univariate models indicated significant effects of age, residence status, and ethnic group on the score of conservation attitude for C. procera, whereas age, residence status, gender, and ethnic group had a significant effect on the score of conservation attitude for L. lanceolata (Fig. 6). The parsimonious model from the model selection procedure indicated that the socioeconomic factors associated with conservation attitudes toward C. procera and L. lanceolata were not the same (Table 2). Age of informants, residence status, and oil market opportunities were identified as significant factors influencing conservation attitude toward C. procera. Adult and old informants showed similar and better conservation attitudes for $C$. procera than young informants (est. Young $=-1.90, p=0.006$ ). Informants in villages with market opportunities for $C$. procera oil showed better conservation attitudes (est. $=5.35, p=$ $0.027)$ than informants in villages with no market opportunities (Table 2). Similarly, indigenous informants had better conservation attitudes (est. Indigenous $=2.90, p=$ $0.001)$ for $C$. procera than non-residents. Concerning $L$. lanceolata, only age and gender were significantly associated with conservation attitudes for this species. As for C. procera, adult and older informants had a better conservation attitude for $L$. lanceolata than younger 

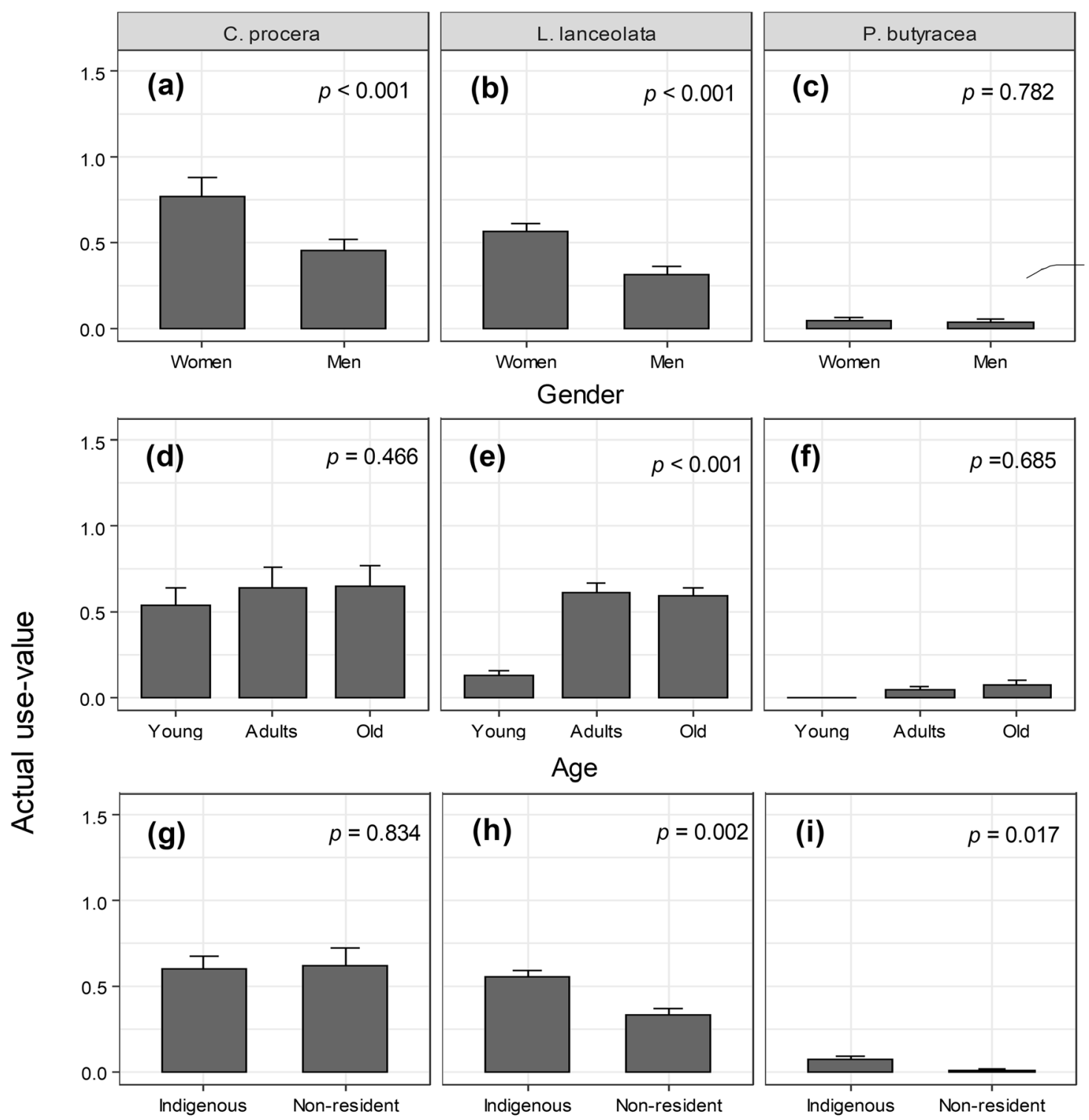

(i)

$p=0.017$

Residence status
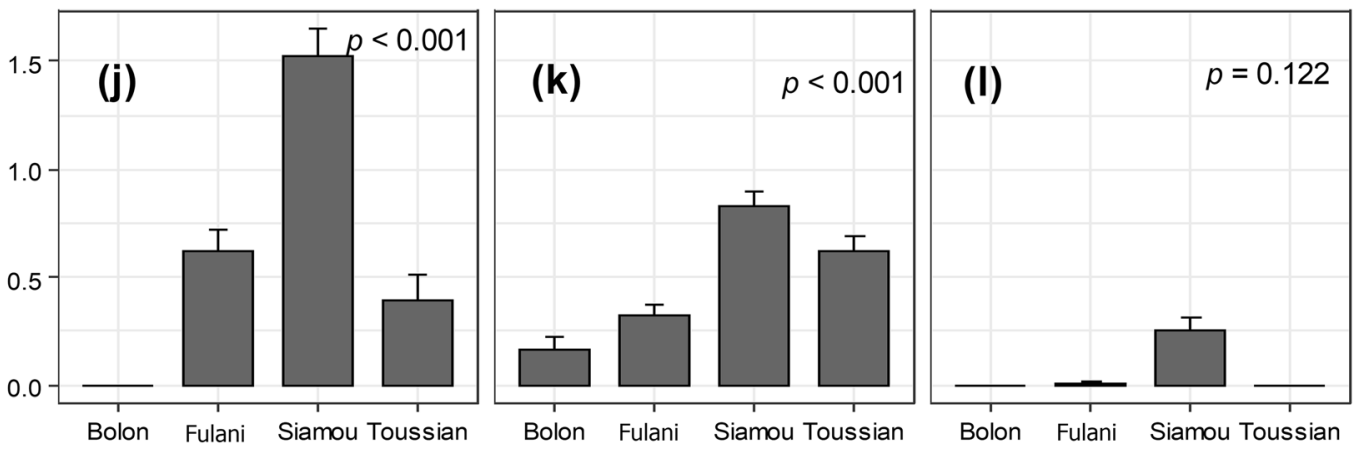

Ethnic group

Fig. 4 Relationship between actual UV of IOS and informants' gender, age, ethnic group, and residence status 
Table 1 Socio-demographic factors associated with actual use-value UV of the three IOS: summary of the parsimonious Poisson generalized mixed model

\begin{tabular}{|c|c|c|c|c|c|c|c|c|c|}
\hline \multirow[t]{2}{*}{ Terms of the model } & \multicolumn{3}{|l|}{ C. procera } & \multicolumn{3}{|l|}{ L. lanceolata } & \multicolumn{3}{|l|}{ P. butyracea } \\
\hline & est. (se) & $z$ & p. & est. (se) & Z & $p$ & est. (se) & Z & $p$ \\
\hline Intercept & $-9.49(2.53)$ & -3.75 & 0.001 & $-1.22(0.37)$ & -3.30 & 0.001 & $-12.06(3.34)$ & -3.60 & 0.001 \\
\hline Age (years old) & - & - & - & $-0.03(0.17)$ & -0.17 & 0.863 & - & - & - \\
\hline Young & - & - & - & $-1.58(0.29)$ & -5.38 & 0.001 & - & - & - \\
\hline Gender (men) & $-0.53(0.14)$ & -3.66 & 0.001 & $-0.58(0.17)$ & -3.40 & 0.001 & - & - & - \\
\hline Residence status (indigenous) & - & - & - & - & - & - & $2.48(1.04)$ & 2.39 & 0.017 \\
\hline Ethnic group (Fulani) & - & - & - & $0.67(0.38)$ & 1.78 & 0.074 & - & - & - \\
\hline Siamou & - & - & - & $1.60(0.39)$ & 4.16 & 0.001 & - & - & - \\
\hline Toussiam & - & - & - & $1.32(0.38)$ & 3.44 & 0.001 & - & - & - \\
\hline Var Village & 88.38 & & & 0.00 & & & 60.22 & & \\
\hline$R_{\text {Marginal }}^{2}$ & 0.07 & & & 42.65 & & & 2.13 & & \\
\hline$R^{2}$ Conditionnel & 90.07 & & & 42.65 & & & 85.10 & & \\
\hline
\end{tabular}

Reference levels were Women for gender, Adult for age, Non-resident for residence status, and Bolon for ethnic group

est. estimates, se standard error, $Z Z$ statistics, $p$. $p$ value

Only terms of significant factors are shown, - = non-significant terms

informants. Women had better conservation attitudes (est. $_{\text {Men }}=-1.45, p=0.001$ ) than men towards L. lanceolata. The among-village variation was less important for L. lanceolate. This was in contrast to C. procera, which showed a significant large variation across villages (see differences between conditional and marginal $R^{2}$, Table $2)$, reflecting the effect of geographical location.

\section{Factors affecting farmers' ability to identify plus trees of IOS}

Identification of plus trees among the three IOS was based on two criteria namely "high oil yield" and "good oil quality," which were determined by oil extraction experience. Overall, "good oil quality" was the predominant criterion for the selection of plus trees, irrespective of the IOS (Fig. 7). Most people cited the two criteria for the selection of L. lanceolata followed by $C$. procera. Trees of $P$. butyracea were less cited for plus trees selection (Fig. 7). Good oil quality for C. procera (mainly used for medicinal purposes) was based on the oil bitterness because this was thought to determine medicinal efficacy. Good oil quality for L. lanceolata and P. butyracea (mainly used for food purposes) was based on the oil color and taste.

The selection of plus trees based on high oil yield was significantly and positively associated with conservation attitudes for $C$. procera, indicating that the better the conservation attitude, the higher the likelihood for the informant to select plus trees based on high oil yield (Table 3). The other two species did not show any significant relationship with the socio-economic factors with regard to this criterion (Table 3). However, the selection of plus trees for $C$. procera based on good oil quality was significantly associated with age, gender, actual UV, and residence status. Men, adults, elderly, and indigenous informants were more likely to select plus
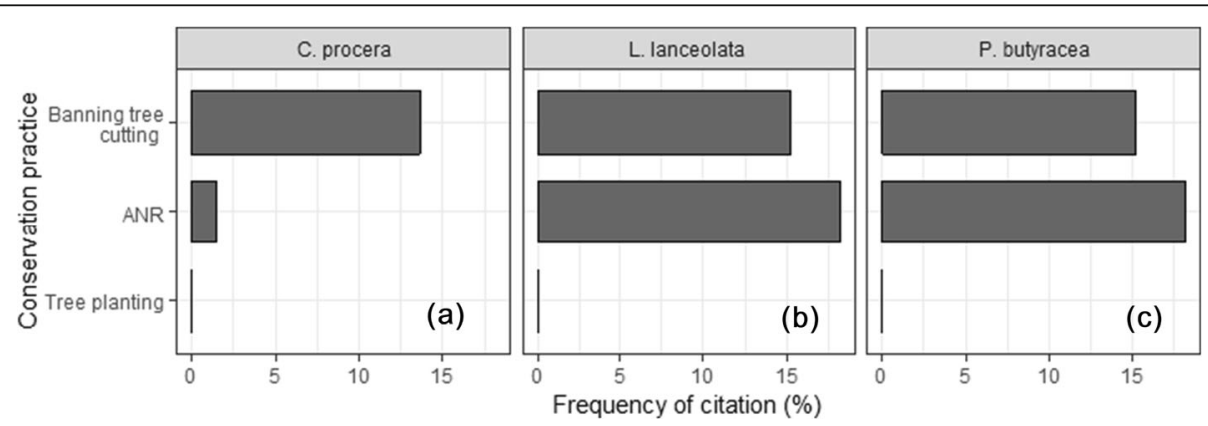

Fig. 5 Proportion of people citing conservation practices. ANR, assisting natural regeneration 

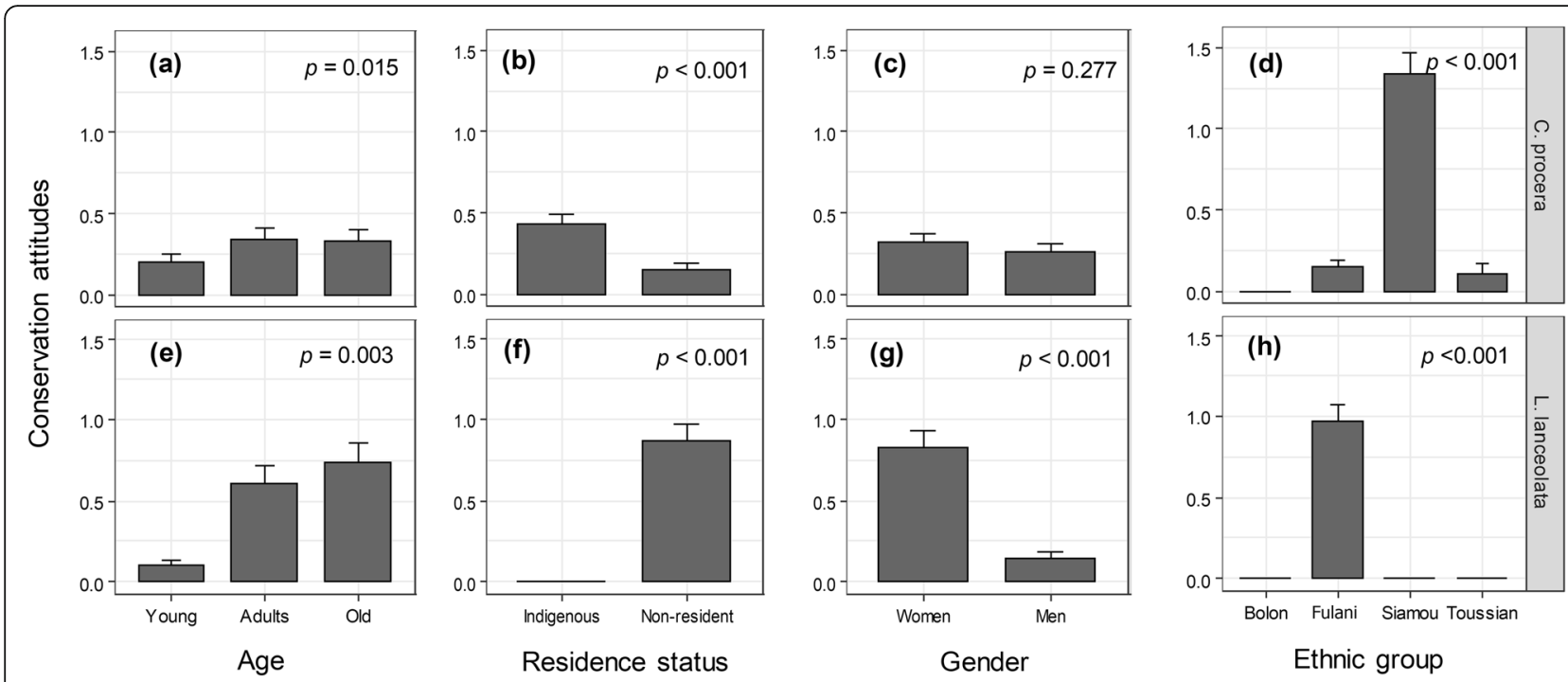

Fig. 6 Relationships between conservation attitude and informants' gender, age, ethnic group, and residence status

trees based on good oil quality than women, young, and non-resident informants. There was a positive association between actual UV and selection of plus trees for C. procera, indicating that the higher the actual UV (i.e., the preference), the higher the ability to select plus trees based on good oil quality. For L. lanceolata, significant factors were age, gender, and actual UV. Although a similar trend was observed for gender and actual UV as for C. procera, old informants mostly selected plus trees of $L$. lanceolata compared to adult and young informants, who showed statistically similar patterns (Table 3). For P. butyracea, age, residence status, and actual UV showed a significant relationship with the selection of plus trees based on good oil quality. Whereas old and adult informants showed a similar trend for selection of plus trees, young informants exhibited the lowest ability to select the trees based on the oil quality criterion. Indigenous informants had a better ability to select plus trees of $P$. butyracea than non-residents, and the higher the preference for $P$. butyracea, the higher was the ability to select its plus trees based on good oil quality (Table 3). Comparable values of conditional and marginal $R^{2}$ for all IOS and selection criteria indicated that there was no or negligible variation across villages i.e., no or negligible variation across geographical locations, irrespective of the IOS (Table 3).

\section{Discussion}

This study assessed the preferences, conservation attitudes, and ability to select plus trees based on seeds' traits of three IOS, and the relationship of these variables with informants' socio-economic factors (age, gender, residence status, ethnic group, and existence of market opportunities in their village). We found differences in preferences, conservation attitudes, and plus tree selection across the three IOS. We also found species-specific patterns regarding socio-economic factors associated with IOS preferences, conservation attitudes, and selection of their plus trees.

Table 2 Socio-economic factors associated with conservation attitudes of IOS: summary of the parsimonious ordinal mixed model

\begin{tabular}{|c|c|c|c|c|c|c|}
\hline \multirow[t]{2}{*}{ Terms of the model } & \multicolumn{3}{|l|}{ C. procera } & \multicolumn{3}{|l|}{ L. lanceolata } \\
\hline & est. (se) & Z & $p$. & est. (se) & $z$ & $p$. \\
\hline Age (years old) & $-0.01(0.57)$ & -0.01 & 0.989 & $0.30(0.22)$ & 1.35 & 0.174 \\
\hline Young & $-1.90(0.69)$ & -2.74 & 0.006 & $-0.92(0.23)$ & -4.03 & 0.001 \\
\hline Residence status (indigenous) & $2.90(0.66)$ & 4.41 & 0.001 & - & - & - \\
\hline Existence of market opportunities (Yes) & $5.35(2.42)$ & 2.21 & 0.027 & - & - & - \\
\hline Gender (men) & - & - & - & $-1.45(0.30)$ & -4.89 & 0.001 \\
\hline Var Village & 12.37 & & & 0.00 & & \\
\hline Significance of village effect & 0.001 & & & 0.122 & & \\
\hline
\end{tabular}

Reference levels were Adult for age, Non-residents for residence status, No for market opportunities, and Women for gender est. estimates, se standard error, $Z Z$ statistics, $p$. $p$ value, - = non-significant terms

Only terms of significant factors are shown 

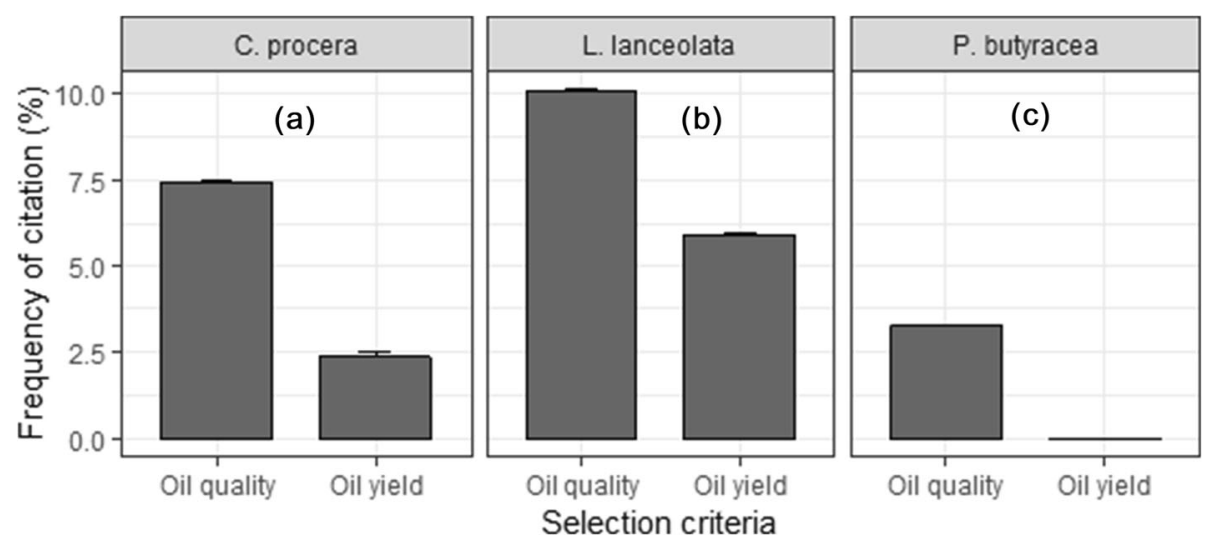

Fig. 7 Variation of selection criteria of plus trees among the three IOS

Preferences, conservation attitudes, and tree selection: differences among the three IOS

A preference for $C$. procera followed by $L$. lanceolata and $P$. butyracea has also been reported in previous studies that focused on their UV [5, 43]. Actually, the most well-known and cited species are those that are most often used and prioritized by communities [56]. The preference for $C$. procera suggests that it probably has a better potential to improve the livelihoods of local communities than the other two IOS. We found a positive correlation between preferences and conservation attitudes for $C$. procera. This was consistent with our prediction that species with higher actual UV receive better conservation actions from users [26] in order to ensure their long-term usage and benefits. However, this expectation was not confirmed for L. lanceolata because its conservation attitude was not significantly correlated with UV. Furthermore, L. lanceolata despite having lower UV (0.44 \pm 0.03 vs. $0.61 \pm 0.06)$, received slightly better conservation attitudes than $C$. procera. The reason could be linked to the differences in the uses of the species by local people. Indeed, oil from $C$. procera seeds is

Table 3 Socio-economic factors associated with informants' ability to identify plus trees of IOS: summary of the parsimonious binomial model

\begin{tabular}{|c|c|c|c|c|c|c|c|c|c|}
\hline & \multicolumn{3}{|l|}{ C. procera } & \multicolumn{3}{|l|}{ L. lanceolata } & \multicolumn{3}{|l|}{ P. butyracea } \\
\hline & est. (se) & Z & $p$ & est. (se) & Z & $p$ & est. (se) & Z & $p$ \\
\hline \multicolumn{10}{|l|}{ High productive tree } \\
\hline Intercept & $-6.59(1.27)$ & -5.16 & 0.001 & - & - & - & - & - & - \\
\hline Conservations attitudes & $1.80(0.45)$ & 4.03 & 0.001 & - & - & - & - & - & - \\
\hline Var.Village & 0.00 & & & - & & & - & & \\
\hline$R_{\text {Marginal }}^{2}$ & 45.03 & & & - & & & - & & \\
\hline$R^{2}$ Conditional & 45.03 & & & - & & & - & & \\
\hline \multicolumn{10}{|l|}{ Good oil quality tree } \\
\hline Intercept & $-6.98(1.27)$ & -5.51 & 0.001 & $-8.61(1.32)$ & -6.51 & 0.001 & $-3.31(0.54)$ & -6.15 & 0.001 \\
\hline Gender (men) & $2.40(0.82)$ & 2.94 & 0.003 & $2.79(0.61)$ & 4.55 & 0.001 & - & - & - \\
\hline Age (years old) & $0.40(0.65)$ & 0.61 & 0.542 & $3.16(0.70)$ & 4.77 & 0.001 & $0.74(0.19)$ & 0.04 & 0.969 \\
\hline Young & $-1.36(0.65)$ & -2.10 & 0.036 & $-2.55(0.52)$ & 0.00 & 0.989 & $-3.03(0.18)$ & -1.65 & 0.001 \\
\hline Resident status (indigenous) & $4.07(0.94)$ & 4.30 & 0.001 & - & - & - & $4.95(1.79)$ & 2.76 & 0.006 \\
\hline Actual use value & $1.18(0.38)$ & 3.11 & 0.009 & $3.25(0.62)$ & 5.23 & 0.001 & $5.28(0.56)$ & 9.48 & 0.001 \\
\hline Var.village & 1.29 & & & 1.99 & & & 0.00 & & \\
\hline$R_{\text {Marginal }}^{2}$ & 41.05 & & & 97.27 & & & 99.92 & & \\
\hline$R^{2}$ Conditional & 57.66 & & & 98.29 & & & 99.92 & & \\
\hline
\end{tabular}

Reference levels were Adult for age, Non-residents for residence status, and Women for gender est. estimates, se standard error, $Z Z$ statistics, $p$. $p$ value, - = non-significant terms

Only terms of significant factors are shown 
mainly used for medicinal purposes whereas that from $L$. lanceolata is used for human food [5, 57]. Assuming that food species are often prioritized because food is one of the most important basic needs, it is likely that C. procera receives fewer conservation actions compared to $L$. lanceolata. These results suggest that the willingness for better management of a species is primarily linked to species UV and its contribution to people livelihoods. Nonetheless, only a small proportion of informants actually practiced a conservation action toward these two species, and no conservation effort was reported for $P$. butyracea. Lophira lanceolata is a savanna species, contrary to the other two IOS which are gallery forest tree species. Because savannas are continuously cleared for farming and $L$. lanceolata is not listed as a priority species for special protection measures (Law No. 003-2011/ AN of Article 44 on the Forest Code in Burkina Faso), trees of these species are exposed to cutting during land clearing in many places [58], making it more vulnerable [14-16]. The fact that cultivation was not practiced for any of the species might be linked to lack of local support for these species planting, and to some extent the lack of suitable management skills of these indigenous species, because most efforts were placed on exotic species [19].

Local knowledge and preferences provide information that is useful for domestication programs. In particular, an understanding of whether local people are already selecting materials among indigenous trees and the criteria locally used in selecting them have an added value for the process. Our results suggest that irrespective of the IOS, oil quality was the primary local criterion for plus tree identification, followed by the oil yield at extraction. Quality is an important factor in both commercialization and household self-consumption of oil [59, 60]. The preference based on oil quality can be explained by the fact that oils of the studied IOS are commonly used in cosmetics and human food and often in association with shea butter. For example, shea butter is often associated with C. procera oil in cosmetic treatments, whereas shea butter is associated with the butter of P. butyracea for human food consumption. For C. procera oil, quality is associated with oil bitterness (the more bitter, the better), and color (high clarity is desirable). Oil that is not of good quality can be linked to inadequate methods of seed storage and the processes of oil extraction, which are tightly linked to experience in the field. This is why oil extraction is commonly practiced by older informants than younger ones. This is consistent with observations by Gueye et al. [11] in Senegal and Rwanda, where older women had more practice and better knowledge of $C$. procera seed oil extraction than youngster. For L. lanceolata and P. butyracea, quality is mostly associated with taste which is expected due to their food uses.
Socio-demographic factors associated with oil plant species preferences, conservation attitudes, and selection of "plus trees"

Although a species-specific pattern was observed, our results support that informants' age, gender, ethnic group, residence status, and geographical location (village) are important factors in understanding IOS preferences. Similar results were observed for conservation attitudes and the ability of informants to select plus trees based on seed traits.

Consistent with our prediction of a positive relationship between preferences and gender, women had a higher UV for $C$. procera than men. Similar results were reported for the shea butter, $V$. paradoxa, another multipurpose IOS in Sub-Saharan Africa [3]. The genderbiased preference is often explained by the fact that men and women do not generally use forest resources in the same way [61]. Women are more specialized in the collection of nuts and seeds, and keener to provide the household with non-timber forest products [3]. As a result, women are expected to be more prone to the conservation of forest resources than men [62, 63]. Our results contrasted with this expectation for C. procera in Kénédougou province where men and women were equally involved in its conservation. However, we found a positive correlation between conservation attitudes and the existence of market opportunities for C. procera. This implies that the provision of market opportunities can lead to positive attitudes of local people toward the management of natural resources, as reported by N'Danikou et al. [30] in Benin for Vitex doniana and Akinnifesi et al. [64] in southern Africa for Miombo indigenous fruit trees. Provision of market opportunities has also been suggested as a key action for the sustainable management of trees, tree genetic resources, and the livelihoods of rural communities [65]. The economic incentives resulting from the rising demand for the oil of C. procera have brought local people to implement some preservation actions including ANR and the banning of tree cutting. An additional reason for this positive conservation attitude might be linked to the sharp decline of gallery forest areas [66], which has resulted in a regression of the species natural populations during recent years. Therefore, to protect their environment and fight against the shrinkage of the stream bed, rural communities are becoming more involved in species management actions. Sustainable management of wild species is a participation-driven process in which different forest resources users and stakeholders are involved. Once the priority species have been identified, another important step is to select individual trees that meet the criteria sought by local communities, because they are the central stakeholders. In the case of C. procera, informants orient their selection toward trees that give good oil 
quality and to a lesser extent high oil yield at extraction. As predicted, we found that people with better conservation attitudes were more likely to identify plus trees, but based on high oil productivity rather than good oil quality. Similarly, the higher the actual UV, the more likely the informant was to select trees based on good oil quality. Surprisingly, we did not find evidence that women were more likely to identify plus trees compared to men, but our results support the prediction of a positive relationship of age and residence status with aptitude to select plus trees. The result that men were more likely than women to identify good oil quality tree can be explained by the fact that in Kénédougou province and elsewhere in Burkina Faso especially for the Toussian ethnic group, (i) men often consume the nut of C. procera as a bitter kola when drinking "Dodo," a fermented drink based on cereals (e.g., sorghum), and (ii) men often use the nuts of $C$. procera for magico-religious purposes in traditional medicine [43, 57]. These common uses are likely to make the men very familiar with the quality of the species nuts and its oil. However, the findings that men, adult and old, and indigenous informants were more likely than women, young, and nonresident informants to identify good oil quality trees suggests that these social categories are of high importance for the selection of germplasm for breeding or genetic improvement of $C$. procera in Kénédougou province. Our results for $C$. procera did not support either the hypothesis of a positive relationship of informant age and residence status with the species UV, or the expectation of differences among ethnic groups (final model after variable selection, see Table 1 ). This might be partly attributed to the fact that the species is relatively widespread and familiar to communities such that everyone knows and uses it [67]. Among the three IOS, C. procera was actually the most common gallery forest species in the area and the most valorized. This absence of a difference among ethnic groups might also be linked to the fact that we did not look at specific uses for which qualitative differences among ethnic groups can arise, or that the effect of ethnic group was confounded with another factor (e.g., village) as the univariate test showed significant variation among ethnic groups (see Fig. 4).

Similar to C. procera, P. butyracea is a specie that grows naturally in gallery forests of semi-arid areas and is subject to the same threats-shrinking of natural habitats resulting from the expansion of agriculture landand has a relatively restricted distribution compared to C. procera $[4,6,14]$. However, contrary to C. procera, our results for $P$. butyracea support the prediction of a positive relationship of IOS UV and resident status: indigenous informants had higher UV compared to nonresidents. Many parts of the species are exploited for medicinal purposes, especially by indigenous people.
The reason why indigenous informants had higher actual UV can be explained by the relatively limited access to habitats of the species in Kénédougou province. Indeed, gallery forests consist of dense vegetation and sometimes shelter ritual sites with access restricted to local "Dozo" healers and hunters, native to the villages [68]. These indigenous people should have an interest in conserving the resources, but this was not the case for P. butyracea in Kénédougou. This might be linked to the scarcity of the species [4] in addition to the lack of marketing opportunities for its products in Kénédougou province. This lack of market opportunities might partly explain why this factor was not significant for any of the three response variables (preferences, conservation attitudes, and aptitude to select plus trees) for this species. Consistent with our prediction, we also found a positive relationship of ability to identify plus trees of $P$. butyracea with the informants' UV of the species, residence status, and age as found for C. procera but with a different intensity (see the coefficients, Table 3 ). The indigenous community mostly used the criterion of oil quality in selecting trees for seed collection [68]. This knowledge was certainly acquired from their ancestors who used local oils for traditional pharmacopeia, food, and cultural rites. No effect of gender was detected for informants' ability to select plus trees based on the criterion of good oil quality, suggesting that both men and women contributed equally in identifying trees producing good oil quality. The lack of differences between men and women regarding this ability might be linked to the fact that the species is less used (lower UV) and that women are not specialized in the production of this species' seed oil.

Our predictions of positive relationships between informants' preference and their gender, age, and resident status and differences among ethnic groups proved true for L. lanceolata (see Fig. 4), although the effect of residence status became insignificant when including multiple variables in the model (see Table 1). Our predictions also proved true for conservation attitudes (see Fig. 6), although only gender and age were finally retained after simplification of the model including all variables. The finding that old informants and women had higher actual UV is likely linked to the fact that knowledge accumulation is a time-related process and to division of labor, respectively, but also sociological contexts as observed for C. procera. Young people are also increasingly less interested in traditions, including uses of local resources due to exposure to western practices [69] which in addition to the time-dependent accumulation of knowledge on species uses, may also explain the low UV for young people. The division of labor and sociological context probably led to higher knowledge and specialization of old women for L. lanceolata oil extraction and uses, which resulted in higher preferences 
than men, as we predicted. Similar findings have been reported for the shea butter tree, V. paradoxa [38]. This preference probably explains why old women have better conservation attitudes toward this species than men. Contrary to the case of $C$. procera, our results did not support the prediction that the existence of market opportunities would imply better conservation attitudes. This is probably because such opportunities and seed transformation are not yet well developed for this species compared to C. procera. Similar to C. procera, we found that men had a higher likelihood than women in identifying plus trees despite not being particularly involved in their oil extraction. In Kénédougou province, men are the owners of land, as also reported for example in a study in Benin by Dadjo et al. [70]. Those who have trees of L. lanceolata on their land linked the oil quality of these trees to the presence of ants. According to them, trees infested by ants will produce a better oil quality. According to their belief, ants are attracted by "good things." This may explain why men had higher aptitude than women in identifying "plus trees" based on oil quality. Ant-plant protective mutualism is a wellknown relationship with many benefits for plants in community ecology [71]. However, whether this protective mutualism results in better oil quality for the protected plants remains a question that requires further investigation. Consistent with our predictions, there was also a positive relationship of aptitude to identify plus trees in L. lanceolata and informants' age, residence status, and preferences for the species. Therefore, like for C. procera, adults and old people in addition to indigenous people can significantly contribute to the selection of interesting material for a domestication program of $L$. lanceolata.

\section{Implications for the sustainable management of the three IOS}

Carapa procera was the most well-known species with the highest UV indicating this species to have a higher potential for improving the livelihoods of local people. Not all factors examined appear to be relevant for all species. Therefore, management actions should also be species-specific. Although a particular focus on women, adults, old persons, and indigenous people is relevant when designing the management of some species (e.g., C. procera and L. lanceolata), it may not be relevant for others (e.g., $P$. butyracea). The fact that no conservation practice was recorded for $P$. butyracea, whereas $L$. lanceolata received relatively better conservation attitudes than $C$. procera is suggesting that management actions can take advantage of existing practices on these two species, and improve them for better delivery. In contrast, for $P$. butyracea, higher attention is needed to ensure that the species is well conserved. The findings that adult and old informants showed a similar and better conservation attitude for $C$. procera than young informants suggest that those categories would be good stakeholders in planning conservation and sustainable management actions for this species. We found a positive association between the existence of market opportunities and better conservation attitudes for C. procera oil. Therefore, creating market opportunities can bring local people to adopt better management practices that will ultimately ensure the sustainable management of indigenous resources. Nevertheless, a multi-platform approach combining local people, NGOs, for profit organizations, and national offices of forest resources management is needed to ensure that the exploitation of resources is sustainable.

The conservation actions reported include protection in agroforestry parks, ANR, and tree planting. These actions have been successfully implemented for some indigenous plants like $V$. paradoxa, Parkia biglobosa (Jacq.) R. Br. ex G. Don, Lannea microcarpa Engl. \& K. Krause, Sclerocarya birrea (A. Rich.) Hochst., Piliostigma reticulatum (DC.) Hochst., and P. butyracea Sabine [23-25]. For $V$. paradoxa, protection in agroforestry parks has improved fruit production [72]. A rotational harvest can also be taught to rural communities. For this measure to be effective, it will be necessary to promote the diversification of activities other than oil extraction. This may require further capacity building of local communities, and providing them with some facilities (e.g., equipment). For instance, in the Akonolinga locality of Cameroon, the need for domestication of Ricinodendron heudelotii (Baill.) Pierre ex Heckel was not a priority for rural communities until the acquisition specialized nut crushing machine. In Morocco, the same observation was made for $A$. spinosa, where the modernization of its oil extraction favors its domestication. In order to implement domestication programs, it is necessary to consider interesting traits of trees identified by rural communities with regard to good oil quality. For all three IOS, key stakeholders who will guide this process should be both adult and old people, irrespective of their gender. Thereby, we suggest participatory approaches that integrate these key informants for successful sustainable management programs of these species.

\section{Conclusion}

This study provides evidence that the preferences, attitudes for resource conservation, and abilities of Kénédougou rural communities to select plus trees for oilseed exploitation are species-specific. The relevance of factors such as age, gender, residence status, existence of commercialization opportunities, and geographical location (village) depended not only the species but also the variables of interest (here preferences, attitudes for 
resource conservation, and abilities to select plus trees for oil-seed extraction). Carapa procera was preferred compared to the other two species. We also demonstrated that the actual UV was associated with the ability to identify and select plus trees for oil-seed exploitation for C. procera. Promoting and better structuring the value chain of this species through economic and financial incentives can significantly improve livelihoods of local people while conserving its natural populations. This is expected to guarantee the sustainable exploitation of the species and serve as a good example for the other two species, namely L. lanceolata and $P$. butyracea. Thus, if rural communities are aware of the income opportunities offered by both species, they would receive more attention with regards to their conservation. Consequently, the three IOS would be rationally and sustainably exploited for household consumption and commercial purposes.

\section{Acknowledgements}

SKV acknowledges the support of the Wallonie-Bruxelles International Postdoctoral Fellowship for Excellence, Belgium (Fellowship \# SUB/2019/443681). Authors are thankful to women associations for oil production in the Kénédougou province for their collaboration. The authors are grateful to the anonymous reviewers for the comments on the earlier version of this paper.

\section{Authors' contributions}

FRST and SKV conceived the work with advices from AO. FRST collected the data. FRST and SKV processed the data. SKV and RJT performed the statistical analyses. FRST and SKV drafted the manuscript with contribution of AO and RJT. AO supervised the work. All authors read and approved the final manuscript.

\section{Funding}

This research was supported by the DANIDA (Danish International Development Agency) through the QualiTree project (Projet no.10-002 AU),

\section{Availability of data and materials}

The datasets used and/or analyzed in the current study are available from the corresponding author on reasonable request.

\section{Ethics approval and consent to participate}

Individual consent to participate in the study was obtained prior to the administration of the questionnaire.

Only people that consented to participate in the study were considered.

\section{Competing interests}

The authors declare that they have no competing interests.

\section{Author details}

${ }^{1}$ Centre Universitaire de Gaoua, Université Nazi BONI, 01 BP 1091, Bobo-Dioulasso 01, Burkina Faso. ${ }^{2}$ Laboratoire de Biologie et Ecologie Végétales, Université Joseph KI-ZERBO, 03 BP 7021, Ouagadougou 03, Burkina Faso. ${ }^{3}$ Laboratoire de Biomathématiques et d'Estimations Forestières, Faculté des Sciences Agronomiques, Université d'Abomey-Calavi, 04 BP, 1525 Cotonou, Bénin. ${ }^{4}$ Evolution Biologique et Ecologie, Faculté des Sciences, Université Libre de Bruxelles, CP160/12, Av. F. D. Roosevelt 50, BE-1050 Bruxelles, Belgique.

Received: 11 February 2020 Accepted: 15 July 2020 Published online: 23 July 2020

\section{References}

1. Tiétiambou, F.R.S., Salako, K.V., Tohoun, J.R. et al. Local preferences for three indigenous oil-seed plants and attitudes towards their conservation in the Kénédougou province of Burkina Faso, West-Africa. J Ethnobiology Ethnomedicine. 2020;16(43). https://doi.org/10.1186/s13002-020-00393-1.
2. Gaoue OG, Sack L, Ticktin T. Human impacts on leaf economics in heterogeneous landscapes: the effect of harvesting non-timber forest products from African mahogany across habitats and climates. Journal of Applied Ecology. 2011;48:844-52.

3. Saussey M, Maïzi PM, Muchnik J. Nouvelles formes de reconnaissance des femmes burkinabè dans la production collective de beurre de karité; 2008

4. Lankoandé B, Ouédraogo A, Boussim Jl, Lykke AM. Identification of determining traits of seed production in Carapa procera and Pentadesma butyracea, two native oil trees from riparian forests in Burkina Faso, West Africa. Biomass and Bioenergy. 2017;102:37-43.

5. Ouédraogo A, Lykke AM, Lankoandé B, Korbéogo G. Potentials for promoting oil products identified from traditional knowledge of native trees in Burkina Faso. Ethnobotany Research and Applications. 2013;11:071-83.

6. Thiombiano A, Schmidt M, Dressler S, Ouédraogo A, Hahn K, Zizka G: Catalogue des plantes vasculaires du Burkina Faso. Boissiera 65. Conservatoire et Jardin botaniques, Genève 2012.

7. Weber N, Birnbaum P, Forget P-M, Gueye M, Kenfack D. L'huile de carapa (Carapa spp., Meliaceae) en Afrique de l'Ouest: utilisations et implications dans la conservation des peuplements naturels. Fruits. 2010;65:343-54.

8. Lankoande B, Ouédraogo A, Boussim JI, Lykke AM. Phenotypic traits of Carapa procera fruits from riparian forests of Burkina Faso, West Africa. J Hortic For. 2015;7:160-7.

9. Van der Vossen H, Mkamilo G. Plant resources of tropical Africa 14: vegetable oils. PROTA, Netherlands. 2007:119-20.

10. Natta A, Sogbégnon R, Tchobo F. Connaissances endogènes et importance du Pentadesma butyracea (Clusiaceae) pour les populations autochtones au Nord Ouest Bénin. Fruit Veg Cereal Sci Biotech. 2010:4:18-25.

11. Gueye M, Kenfack D, Forget P-M. Importance socio-culturelle, potentialités économiques et thérapeutiques du Carapa (Meliaceae) au Sénégal; 2010.

12. Lohlum SA. Proximate composition, amino acid profile and phytochemical screening of Lophira lanceolata seeds. Agriculture, Nutrition and Development: African Journal of Food; 2010. p. 10.

13. Aissi MV, Tchobo PF, Natta AK, Piombo G, Villeneuve P, Sohounhloue DCK, Soumanou MM. Effet des prétraitements post-récolte des amandes de Pentadesma butyracea (Sabine) sur la technologie d'extraction en milieu réel et la qualité du beurre: le cheminement de PT. Smart. Oilseeds and fats. Crops and Lipids. 2011;18:384-92.

14. Traore L, Ouedraogo I, Ouedraogo A, Thiombiano A. Perceptions, usages et vulnérabilité des ressources végétales ligneuses dans le Sud-Ouest du Burkina Faso. International Journal of Biological and Chemical Sciences. 2011;5.

15. Rasmussen K, Fog B, Madsen JE. Desertification in reverse? Observations from northern Burkina Faso. Global Environmental Change. 2001;11:271-82.

16. Sop T, Oldeland J, Schmiedel U, Ouedraogo I, Thiombiano A. Population structure of three woody species in four ethnic domains of the sub-sahel of Burkina Faso. Land Degradation \& Development. 2011;22:519-29.

17. Atato A, Wala K, Batawila K, Lamien N, Akpagana K. Edible wild fruit highly consumed during food shortage period in Togo: state of knowledge and conservation status. Journal of Life Sciences. 2011;5:1046-57.

18. Chominot A. Valorisation des plantes médicinales par l'industrie pharmaceutique: complémentarités et contradictions; 2000.

19. Etongo D, Djenontin INS, Kanninen M, Fobissie K. Smallholders' tree planting activity in the ziro province, southern burkina faso: impacts on livelihood and policy implications. Forests. 2015;6:2655-77.

20. Augusseau X, Nikiéma P, Torquebiau E. Tree biodiversity, land dynamics and farmers' strategies on the agricultural frontier of southwestern Burkina Faso. Biodiversity \& Conservation. 2006;15:613-30.

21. Sawadogo H, Hien F, Sohoro A, Kambou F. Pits for trees: how farmers in semiarid Burkina Faso increase and diversify plant biomass. Farmer innovation in Africa: A source of inspiration for agricultural development. 2001.

22. Ræbild A, Bassirou B, Lillesø J-PB, Emma-Lucie Y, Damas P: Farmers' planting practices in Burkina Faso. A survey carried out by the project'Improved Seed Supply for. and no Forest \& Landscape Working Papers 2005.

23. Belem B, Nacoulma BMl, Gbangou R, Kambou S, Hansen HH, Gausset Q, Lund S, Raebild A, Lompo D, Ouedraogo M. Use of non wood forest products by local people bordering the "Parc National Kaboré Tambi", Burkina Faso. The Journal of Transdisciplinary Environmental Studies. 2007;6: $1-21$.

24. Lovett P, Haq N. Diversity of the Sheanut tree (Vitellaria paradoxa CF Gaertn.) in Ghana. Genetic Resources and Crop Evolution. 2000;47:293-304. 
25. Yelemou B, Bationo BA, Yaméogo G, Rasolodimby JM. Gestion traditionnelle et usages de Piliostigma reticulatum sur le Plateau central du Burkina Faso. Bois \& Forêts des Tropiques. 2007;291:55-66.

26. Kristensen M, Lykke AM. Informant-based valuation of use and conservation preferences of savanna trees in Burkina Faso. Economic Botany. 2003;57: 203-17.

27. Gaoue OG, Coe MA, Bond M, Hart G, Seyler BC, McMillen H. Theories and major hypotheses in ethnobotany. Economic Botany. 2017;71:269-87.

28. Mukadasi B, Kaboggoza JR, Nabalegwa M. Agroforestry practices in the buffer zone area of Mt Elgon National Park, eastern Uganda. African journal of ecology. 2007;45:48-53.

29. Gandji K, Salako VK, Fandohan AB, Assogbadjo AE, Kakaï RLG. Factors determining the use and cultivation of Moringa oleifera Lam. in the Republic of Benin. Economic botany. 2018;72:332-45

30. N'Danikou S, Achigan-Dako EG, Tchokponhoue DA, Agossou CO, Houdegbe CA, Vodouhe RS, Ahanchede A. Modelling socioeconomic determinants for cultivation and in-situ conservation of Vitex doniana Sweet (Black plum), a wild harvested economic plant in Benin. Journal of ethnobiology and ethnomedicine. 2015:11:28.

31. Balima LH, Nacoulma BMI, Ekué MRM, Kouamé FNG, Thiombiano A: Use patterns, use values and management of Afzelia africana Sm. in Burkina Faso: implications for species domestication and sustainable conservation. Journal of ethnobiology and ethnomedicine 2018, 14:23.

32. Ewédjè E-EB, Parmentier I, Natta A, Ahanchédé A, Hardy OJ. Morphological variability of the tallow tree, Pentadesma butyracea Sabine (Clusiaceae), in Benin. Genetic resources and crop evolution. 2012;59:625-33.

33. Gwali S, Nakabonge G, Okullo JBL, Eilu G, Nyeko P, Vuzi P. Morphological variation among shea tree (Vitellaria paradoxa subsp. nilotica)'ethnovarieties' in Uganda. Genetic resources and crop evolution. 2012;59:1883-98.

34. Assogbadjo AE, Glèlè Kakaï R, Chadare F, Thomson L, Kyndt T, Sinsin B, Van Damme P. Folk classification, perception, and preferences of baobab products in West Africa: consequences for species conservation and improvement. Economic botany. 2008;62:74-84.

35. Whitney CW, Luedeling E, Tabuti JR, Nyamukuru A, Hensel O, Gebauer J Kehlenbeck K. Crop diversity in homegardens of southwest Uganda and its importance for rural livelihoods. Agriculture and Human Values. 2018;35: 399-424.

36. Heubach K, Wittig R, Nuppenau E-A, Hahn K. The economic importance of non-timber forest products (NTFPs) for livelihood maintenance of rural west African communities: a case study from northern Benin. Ecological Economics. 2011;70:1991-2001.

37. Shackleton S, Paumgarten F, Kassa H, Husselman M, Zida M. Opportunities for enhancing poor women's socioeconomic empowerment in the value chains of three African non-timber forest products (NTFPs). International Forestry Review. 2011;13:136-51.

38. Elias M, Carney J. African shea butter: a feminized subsidy from nature Africa. 2007:77:37-62.

39. de Albuquerque UP, Hanazaki N. Five problems in current ethnobotanical research-and some suggestions for strengthening them. Human Ecology. 2009;37:653-61.

40. Assogba GA, Fandohan AB, Salako VK, Assogbadjo AE. Usages de Bombax costatum (Malvaceae) dans les terroirs riverains de la Réserve de biosphère de la Pendjari, République du Bénin. Bois \& Forêts des Tropiques. 2017;333: 17-29.

41. Gouwakinnou GN, Lykke AM, Assogbadjo AE, Sinsin B. Local knowledge, pattern and diversity of use of Sclerocarya birrea. Journal of ethnobiology and ethnomedicine. 2011:7:8.

42. de Albuquerque UP. Re-examining hypotheses concerning the use and knowledge of medicinal plants: a study in the Caatinga vegetation of NE Brazil. Journal of ethnobiology and ethnomedicine. 2006;2:30.

43. Tiétiambou FRST, Lykke AM, Korbéogo G, Thiombiano A, Ouédraogo A. Perceptions et savoirs locaux sur les espèces oléagineuses locales dans le Kénédougou, Burkina Faso. Bois \& Forets des Tropiques. 2016;327:39-50.

44. Cuni-Sanchez A, Ngute ASK, Sonké B, Sainge MN, Burgess ND, Klein JA, Marchant R. The importance of livelihood strategy and ethnicity in forest ecosystem services' perceptions by local communities in north-western Cameroon. Ecosystem Services. 2019;40:101000.

45. Lawrence A, Phillips OL, Ismodes AR, Lopez M, Rose S, Wood D, Farfan AJ. Local values for harvested forest plants in Madre de Dios, Peru: towards a more contextualised interpretation of quantitative ethnobotanical data. Biodiversity \& Conservation. 2005;14:45-79.
46. Peppin DL, Fulé PZ, Lynn JC, Mottek-Lucas AL, Hull Sieg C. Market perceptions and opportunities for native plant production on the Southern Colorado Plateau. Restoration Ecology. 2010;18:113-24.

47. Fontes J, Guinko S. Vegetation and land use's map of Burkina Faso. Explanatory Note Ministry of French Cooperation. 1995:1-57.

48. Bennett BC, Prance GT. Introduced plants in the indigenous pharmacopoeia of Northern South America. Economic botany. 2000;54:90-102.

49. Phillips O, Gentry AH: The useful plants of Tambopata, Peru: I. Statistical hypotheses tests with a new quantitative technique. Economic Botany 1993, 47:15-32.

50. Phillips O, Gentry AH: The useful plants of Tambopata, Peru: II. Additional hypothesis testing in quantitative ethnobotany. Economic Botany 1993, 47: $33-43$.

51. Zuur A, leno EN, Walker N. Saveliev AA. Mixed effects models and extensions in ecology with R. Springer Science \& Business Media: Smith GM; 2009

52. McCullagh P. Regression models for ordinal data. Journal of the Royal Statistical Society: Series B (Methodological). 1980;42:109-27.

53. R Development Core Team: R: a language and environment for statistical computing (Online). Vienna, Austria: R Foundation for Statistical Computing. 2015.

54. Christensen RHB: ordinal—regression models for ordinal data. R package version 2015, 28:2015.

55. Bates D, Mächler M, Bolker B, Walker S: Fitting linear mixed-effects models using Ime4. arXiv preprint arXiv:14065823 2014.

56. Belem B, Olsen CS, Theilade I, Bellefontaine R, Guinko S, Lykke AM, Diallo A, Boussim Jl. Identification des arbres hors forêt préférés des populations du Sanmatenga (Burkina Faso). Bois \& Forets des Tropiques. 2008;298:53-60.

57. Dembélé $U$, Lykke AM, Koné $Y$, Témé $B$, Kouyaté $A M$. Use-value and importance of socio-cultural knowledge on Carapa procera trees in the Sudanian zone in Mali. Journal of ethnobiology and ethnomedicine. 2015; 11:14.

58. Lankoandé B, Ouédraogo A, Boussim Jl, Lykke AM. Natural stands diversity and population structure of Lophira lanceolata Tiegh. ex Keay, a local oil tree species in Burkina Faso, West Africa. Agroforestry systems. 2017;91:85-96.

59. Gwali S, Okullo JBL, Eilu G, Nakabonge G, Nyeko P, Vuzi P. Folk classification of shea butter tree (Vitellaria paradoxa subsp. nilotica) ethno-varieties in Uganda. Ethnobotany research and applications. 2011;9:243-56.

60. Honfo FG, Linnemann AR, Akissoe NH, Soumanou MM, Van Boekel MA. Indigenous knowledge of shea processing and quality perception of shea products in Benin. Ecology of food and nutrition. 2012;51:505-25.

61. Kristensen M, Balslev H. Perceptions, use and availability of woody plants among the Gourounsi in Burkina Faso. Biodiversity \& Conservation. 2003;12: 1715-39.

62. Lynam T, Cunliffe R, Mapaure I. Assessing the importance of woodland landscape locations for both local communities and conservation in Gorongosa and Muanza Districts, Sofala Province, Mozambique. Ecology and Society. 2004:9.

63. Sheil D, Liswanti N. Scoring the importance of tropical forest landscapes with local people: patterns and insights. Environmental Management. 2006; 38:126-36.

64. Akinnifesi F, Kwesiga F, Mhango J, Mkonda A, Chilanga T, Swai R: Domesticating priority miombo indigenous fruit trees as a promising livelihood option for small-holder farmers in Southern Africa. In XXVI International Horticultural Congress: Citrus and Other Subtropical and Tropical Fruit Crops: Issues, Advances and 632. 2002: 15-30.

65. Dawson IK, Leakey R, Clement CR, Weber JC, Cornelius JP, Roshetko JM, Vinceti B, Kalinganire A, Tchoundjeu Z, Masters E. The management of tree genetic resources and the livelihoods of rural communities in the tropics: non-timber forest products, smallholder agroforestry practices and tree commodity crops. Forest Ecology and Management. 2014;333:9-21.

66. Bene A, Fournier A: Végétation naturelle et occupation des terres au Burkina Faso (Afrique de l'ouest). Cinq décennies de changement dans un terroir du pays sદ̀mغे. 2014.

67. Salako KV, Moreira F, Gbedomon RC, Tovissodé F. Assogbadjo AE. Kakaï RLG: Traditional knowledge and cultural importance of Borassus aethiopum Mart. in Benin: interacting effects of socio-demographic attributes and multi-scale abundance. Journal of ethnobiology and ethnomedicine. 2018;14:36.

68. Olivier M, Zerbo P, Boussim Jl, Guinko S. Les plantes des galeries forestières à usage traditionnel par les tradipraticiens de santé et les chasseurs Dozo 
Sénoufo du Burkina Faso. International Journal of Biological and Chemical Sciences. 2012;6:2170-91.

69. Júnior WSF, Santoro FR, Vandebroek I, Albuquerque UP: Urbanization, modernization, and nature knowledge. In Introduction to Ethnobiology. Edited by Albuquerque UP, Nóbrega Alves RR. Cham: Springer International Publishing; 2016: 251-256.

70. Dadjo C, Nyende AB, Salako KV, Hounkpèvi A, Assogbadjo AE. Socioeconomic factors determining conservation and cultivation of Garcinia kola Heckel- a medicinal plant extinct in wild in Benin. Economic Botany. 2020; 2020.

71. Trager MD, Bhotika S, Hostetler JA, Andrade GV, Rodriguez-Cabal MA, McKeon CS, Osenberg CW, Bolker BM. Benefits for plants in ant-plant protective mutualisms: a meta-analysis. PLOS ONE. 2010;5:e14308.

72. Lamien N, Ouédraogo SJ, Diallo OB, Guinko S: Productivité fruitière du karité (Vitellaria paradoxa Gaertn. CF, Sapotaceae) dans les parcs agroforestiers traditionnels au Burkina Faso. Fruits 2004, 59:423-429.

\section{Publisher's Note}

Springer Nature remains neutral with regard to jurisdictional claims in published maps and institutional affiliations.

Ready to submit your research? Choose BMC and benefit from:

- fast, convenient online submission

- thorough peer review by experienced researchers in your field

- rapid publication on acceptance

- support for research data, including large and complex data types

- gold Open Access which fosters wider collaboration and increased citations

- maximum visibility for your research: over $100 \mathrm{M}$ website views per year

At BMC, research is always in progress.

Learn more biomedcentral.com/submissions 